\title{
Gestational Age, Exclusive Breastfeeding, Attitude Complementary Foods Associated with Stunting Infants
}

\author{
Atik Pramesti Wilujeng1* $^{*}$ \\ Institute of Health Science Banyuwangi, Indonesia ${ }^{1}$
}

\section{Article information}

Article history:

Received; October 01st, 2019

Revised: December 10th, 2019

Accepted: January 20th, 2020

\section{Corresponding author:}

Atik Pramesti Wilujeng

Institute of Health Science,

Banyuwangi, Indonesia. Jalan Istiqlah

No. 109 Banyuwangi

Email:

atikpramesti@stikesbanyuwangi.ac.id

International Journal of Nursing and Health Services (IJNHS)

Volume 4, Issue 6, December 20 th 2021

http://doi.org/10.35654/ijnhs.v4i6.543

E-ISSN: 2654-6310

\begin{abstract}
Introduction: Many factors influence the occurrence of stunting in toddlers, but the most important factor influencing the incidence of stunting comes from the mother. Objective: This study aims to analyze the relationship between the gestational age of infants, exclusive breastfeeding, and the mother's attitude in giving complementary foods with the incidence of stunting in infants aged 6-24 months. Method: The research design is Cross-Sectional. The sampling technique used was purposive sampling involving 125 mothers of infants aged 6-24 months. Result: The results found that gestational age $(p$-value $=0.016)$, exclusive breastfeeding ( $\mathrm{p}$-value $=0.027)$ and complementary feeding $(p$-value $=0.00)$ have positive correlation with attitude and complementary feeding. The babies born at an early gestational age are at risk of stunting. Exclusive breastfeeding for infants aged 0-6 months, followed by a positive mother's attitude in preparing and providing quality complementary foods, can reduce the risk of stunting. Therefore nurses' efforts are needed to provide health education to mothers to optimize their role in infant care and nutrition. Recommendation: Health workers, both nurses, and midwives, should increase their role in providing health education to mothers with babies aged 6-24 months about the importance of Antenatal Care, health education about the benefits of breastfeeding and forming of breastfeeding motivators, and providing health education to mothers under five how to arrange a supplementary food menu for toddlers.
\end{abstract}

Keywords: gestational age, breastfeeding, stunting, infant

This is an Open Access article distributed under the terms of the Creative Commons Attribution 4.0 International License CC BY -4.0 


\section{INTRODUCTION}

The SDGs aim to end all forms of malnutrition by 2030. It has been internationally agreed that stunting be reduced by 2025 and eliminated by 2030 . Several countries are struggling to meet this target. Globally In 2019, under-five malnutrition was the most significant contributor to the death of children under five years old (1).

The malnutrition category includes stunting, wasting, and micronutrient deficiency. Malnutrition makes children more susceptible to infectious diseases (2). stunting is a significant contributor to morbidity and mortality in children. This drives policies to prevent child malnutrition and lifelong disabilities, which are global nutrition targets for 2025 (3). Stunting, underweight, and overweight are strongly associated with chronic disease (4).

Malnutrition caused by stunting can damage the growth and development of early childhood. Children who are stunted may experience impaired growth and development, poor cognition, and the spread of repeated infections (5). Babies' optimal growth and development are significant for their future (6).

Stunting is a condition of failure to thrive in children under five years old (infants under five years old) due to chronic malnutrition so that children are too short for their age. Malnutrition occurs since infants with nutritional status based on length or height according to generation according to the 2006 WHO-MGRS (Multicentre Growth Reference Study) standard. The z-score value is less than -2 $\mathrm{SD}$ to $+\mathrm{SD}$ (normal) and $-3 \mathrm{SD}$ to $<-2 \mathrm{SD}$ (stunted) (7).

Nutritional problems, especially stunting in toddlers, can hamper the development of children with negative impacts. It took place in the next life, such as intellectual decline, vulnerability to noncommunicable diseases, decreased productivity to cause poverty, and the risk of giving birth to babies with low birth weight (8). Stunting is considered the main indicator to assess the welfare of children.
Globally, approximately 159 million children under 5 years are stunted, with more than $90 \%$ of them living in low- and middle-income countries (9). Worldwide, nearly 200 million children under the age of 5 are stunted, underweight, or a mixture of both (10).

The Efforts to reduce stunting are carried out through two interventions, namely specific nutrition interventions and sensitive nutrition interventions. One of the particular nutritional interventions carried out is providing additional food to pregnant women, such as blood-added tablets, encouraging early initiation of breastfeeding, encouraging exclusive breastfeeding, and encouraging continued breastfeeding until the age of 23 months accompanied by complementary feeding (11).

Worldwide, nearly 200 million children under the age of 5 are stunted, underweight, or a mixture of both (10). Currently, breastfeeding has been considered the best way of feeding babies because it has been proven to have many benefits, including reducing infant mortality. The longer the breastfeeding period received by the baby, the child will have more intelligence in adulthood (12).

In 2017 there were 151 children under five in the world experiencing stunting $(22 \%)$ (their growth was below their age stage). Approximately $75 \%$ of them came from Southeast Asia or Africa. Stunting in toddlers has a negative impact on national development. In 2017 children under five $(7.5 \%)$ experienced wasting (13).

According to the World Health Organization (WHO), in 2015, about 23\% of children under five were stunted. Taking the average prevalence rate in most Asian countries with $33 \%$, Japan is estimated with $36 \%$ recorded by Matsumoto in 2019. The prevalence of stunting in Indonesia was $37 \%$ and $20.7 \%$ in Malaysia in 2016. Based on the National Health and Morbidity Survey, China's 2014 National Survey recorded the lowest at 3.7\%, and India accounted for the highest rate with $48 \%$ by the 2007 National Health Survey. The contributing factors to the prevalence, as 
mentioned earlier rate are the interactions between genetics, environmental factors, nutritional status, psychosocial and the rate of secular change in growth (14).

Indonesia is part of a country in Southeast Asia with the highest prevalence of stunting. The number of stunting children aged 12-59 years in 2013 was $37.2 \%$, and in 2018 it was 30.8\% (15). In East Java Province in 2020, the number of stunting toddlers (TB/U) is $12.4 \%$, and the percentage of wasting toddlers is $8.0 \%$ (16).

Based on the Banyuwangi health profile in 2019, data on the number of stunting toddlers was obtained with a percentage above $20 \%$. Namely, Kertosari Health Center $25.9 \%$, Gendoh $24.5 \%$, and Creepy $20.4 \%$ (17).

The factors that cause stunting are grouped into three: community, family, and individual factors. Community factors consist of economic, education, health, and sanitation systems. Family factors include inadequate food quality and quantity, family income, the structure of family members, parenting, and health services. In contrast, individual factors that cause stunting are poor nutritional intake, low birth weight, and a history of infectious diseases (18).

Stunting has short and long-term effects, direct and indirect impacts on children. Low birth weight contributes to stunting (19). Based on the research conducted by the researcher, it was found that children who were late for breastfeeding initiation were more at risk of stunting than those who breastfed immediately after birth. Children who are fed fresh milk have less risk of stunting, and children under five who are fed a meat diet (meat, fish, poultry, organ meats) have a lower risk of stunting compared to those who are not well fed (20)

Knowing that the incidence of stunting is still high and the impact that will be caused when a child experiences stunting, it is necessary to identify the risk factors for stunting so that the factors that cause stunting can be controlled. One of the successful efforts is to control the factors that cause stunting (15).
Previous studies have examined several predictors of stunting, focusing on understanding social, economic, environmental, demographic, and biological determinants. However, several studies aim to identify the relationship between cultural norms and beliefs with stunting (21).

Another study has also found factors such as the sex of the child, the child's age and birth weight, birth order, number of siblings, wealth index, mother's education, maternal body mass index, and access to health services to be risk factors for stunting.

Various efforts have been carried out to reduce the incidence of stunting, but the prevalence of stunting is still high. The multisector programs need to apply; however, they still lack, and the operationalization of multisector response is yet to be realized (22).

This study uses a correlation study to examine the factors associated with the incidence of stunting in children less than five years of age. The results of this study are expected to be useful for health researchers and policymakers in reviewing and designing new intervention strategies aimed at reducing the number of stunted children related to infant gestational age, breastfeeding, and PMT.

The results will also provide important information about preventing premature births and Intra Uterine Growth Retardation and increasing the scope of exclusive breastfeeding, and increasing the mother's understanding in preparing complementary feeding so that the incidence of stunting can be reduced (23).

This follows the research results, which states that one of the essential factors that influence stunting in early childhood is birth weight and gestational age of infants (24). This study uses a theoretical approach to the Health Promotion Model. The Health Promotion Model approach in this study is a theoretical perspective exploring the factors and their relationships in health promotion efforts to improve children's health through controlling risk factors for stunting. 
HPM can assist nurses in identifying risk factors for stunting in the Previous mother's behavior in meeting the needs of growth aspect as part of the Individual characteristics and experience. It could be measured from the variables of Exclusive Breastfeeding and Supplementary Feeding (PMT) and on aspects of Interpersonal factors that can be evaluated on the variable infant's gestational age. HPM is a guide for nurses to explore complex processes that motivate mothers to meet their child's nutritional needs so that children can grow up healthy and free from stunting (25)

\section{OBJECTIVE}

This study aims to analyze the relationship between the gestational age of infants, exclusive breastfeeding, and the mother's attitude in giving complementary foods with the incidence of stunting in infants aged 6-24 months.

\section{METHOD}

\section{Design}

This study applied the CrossSectional approach to examine the relationship between the gestational age of infants, exclusive breastfeeding, and mother's attitude in giving complementary foods with the incidence of stunting in infants aged 6-24 months.

\section{Sample and sampling technique}

The samples involved in this study were mothers of infants aged 6-24 months, totaling 125 people selected using the purposive sampling technique. The chosen samples met the inclusion criteria: mothers who had toddlers aged 6-24 months and were willing to be respondents.

\section{The instrument for data collection}

The baby's gestational age instrument used an open questionnaire, which consisted of 1 question. Answers were classified as $<37$ weeks and $37-42$ weeks. The instrument for exclusive breastfeeding used an available questionnaire, which consisted of 1 question with two answer choices, namely exclusive breastfeeding and not exclusive breastfeeding. While measuring the mother's attitude in giving complementary feeding, researchers used a questionnaire from the Ministry of Health of the Republic of Indonesia in 2014, consisting of 9 questions with correct answer choices and wrong.

Each statement item has a choice of answers with a score of 0 for the answers of respondents who chose the wrong answer and a score of 1 for respondents who chose the correct answer, so the total score is 9 . The instrument was used to measure the incidence of stunting. Researchers used an observation sheet. Body length was measured by microtome with $0.1 \mathrm{~cm}$ accuracy. Furthermore, height data is converted into a standardized value (Zscore), then based on the Z-score value of each of these indicators is determined the nutritional status of children under five with criteria -2 SD to + SD (normal) and -3 SD to $<-2 \mathrm{SD}$ (stunted).

\section{Data Collection Process}

Data collection was carried out on April 17th - June 20th, 2021, at the Banyuwangi Regency Health Center. The data collection in this study was carried out by collecting data at the Banyuwangi Regency Health Center in 2021, followed by visiting the homes of each respondent to conduct a height check based on age (TB/U).

Researchers assisted by research assistants carried out the data collection procedure. Before collecting data, the researcher worked an equation of perception with the research assistant regarding research data collection. This research assistant is a cadre.

After the researchers obtained data on the number of babies from the community health center, the researchers coordinated with the regional midwife. Data was collected by inviting mothers of children under five to attend the regional midwife's house. If a baby's mother is not present, the researcher makes a home visit 
for each baby with research data collection assisted by a research assistant.

\section{Data analysis}

The univariate analysis was used to describe the characteristics of respondents. Bivariate analysis with the ChiSquare test identifies the relationship between the independent and dependent variables.

In bivariate analysis, in addition to analyzing the relationship between the independent variable and the dependent variable using the Chi-Square test, the researcher also calculates the Odd Ratio, which aims to measure the chance of the Independent can affect the dependent variable. In SPSS data analysis, the Odd Ratio value is raised by checking Cochran's and Mantel-Haenszel Statistics, then the Odd Ratio OR is shown at the $95 \%$ C.I.for $\operatorname{EXP}(B)$ value.

\section{Ethical consideration}

This research has gone through the ethical feasibility test phase with the number 606/KEPK/STIKES-BWI.

\section{RESULTS}

Data collection was carried out on April 17th - June 20th, 2021, at the Banyuwangi Regency Health Center.

Table 1. Characteristic of respondents

\begin{tabular}{lcc}
\hline $\begin{array}{l}\text { Characteristic of } \\
\text { Respondent }\end{array}$ & F & $\%$ \\
\hline $\begin{array}{l}\text { Mother education, } \\
\quad \text { Primary school }\end{array}$ & 45 & 36 \\
$\quad \begin{array}{l}\text { Junior high school } \\
\quad \text { Senior High School }\end{array}$ & 20 & 16 \\
$\quad \begin{array}{l}\text { College Graduate } \\
\text { Mother's Job }\end{array}$ & 10 & 40 \\
$\quad$ Housewife & 85 & 68 \\
$\quad$ Mother as employee & 40 & 32 \\
\hline $\begin{array}{l}\text { infant's gestational age } \\
\quad \text { <37 Weeks }\end{array}$ & 25 & 20 \\
$\quad$ z37 Weeks & 100 & 80 \\
\hline $\begin{array}{l}\text { Exclusive breastfeeding } \\
\text { Exclusive breastfeeding } \\
\text { Non-Exclusive } \\
\text { breastfeeding }\end{array}$ & 95 & 76 \\
\hline $\begin{array}{l}\text { Mother's behavior in } \\
\text { providing }\end{array}$ & 30 & 24 \\
\hline
\end{tabular}

\begin{tabular}{lcc}
\hline complementary feeding & & \\
\hline Positive & 55 & 44 \\
Negative & 70 & 56 \\
\hline Stunting & & \\
\hline Stunting & 94 & 75 \\
No Stunting & 31 & 25 \\
& & \\
\hline
\end{tabular}

Table 1 shows that the characteristics of respondents based on education level, mothers who have Senior High School education are $50(40 \%)$ followed by $45(36 \%)$. Most of the mothers involved in this study were Housewife 85 people $(68 \%)$. Based on the gestational period, most of the babies born with gestational age 37-42 weeks by $80 \%$, which is at this age is in the mature stage and includes normal gestational age. $76 \%$ of infants received exclusive breastfeeding, and more than $50 \%$ of mothers had a positive attitude in giving complementary foods, while stunting data showed that $94(75 \%)$ infants were in the moderately stunted category.

\section{Table 2 Relationship of Infant's Gestational Age with Stunting}

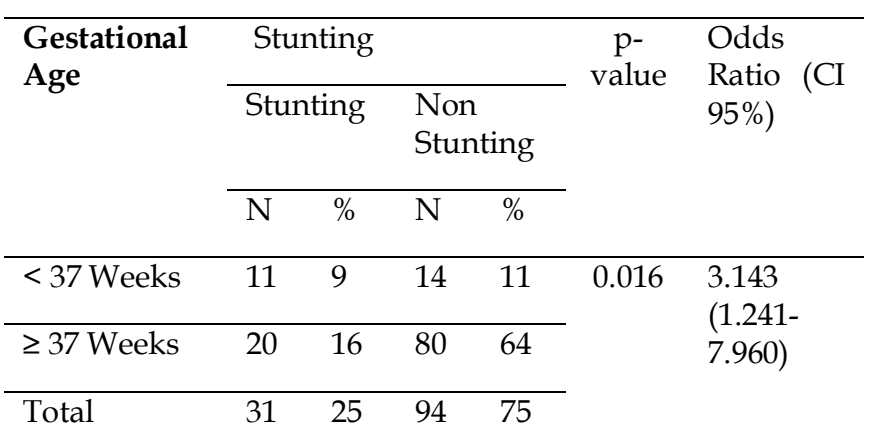

Based on table 2, data shows that babies born at $\geq 37$ Weeks of gestation are not at risk of stunting of 80 babies $(64 \%)$ and stunting of 20 babies (16\%). The analysis results found a relationship between Gestational Age and stunting incidence ( $p$ value was 0.016 and $\mathrm{OR}$ value was 3.143 (95\% CI:1.03-2.35). It could be concluded that babies born with gestational age <37 weeks have a three times greater risk of stunting than babies born with gestational age $\geq 37$ weeks. On the other hand, babies born with gestational age $<37$ weeks at least 1,241 times at risk of stunting, and the most 
significant risk of stunting was 7.960 times.

Table 3. Relationship between exclusive breastfeeding and stunting

\begin{tabular}{|c|c|c|c|c|}
\hline \multirow{3}{*}{$\begin{array}{l}\text { Exclusive } \\
\text { breastfeeding }\end{array}$} & \multicolumn{2}{|c|}{ Stunting } & \multirow{3}{*}{$\begin{array}{l}\mathrm{p}- \\
\text { value }\end{array}$} & \multirow{3}{*}{$\begin{array}{l}\text { Odds } \\
\text { Ratio } \\
\text { (CI } \\
95 \%)\end{array}$} \\
\hline & $\begin{array}{l}\text { Stuntin } \\
\mathrm{g}\end{array}$ & $\begin{array}{l}\text { Non } \\
\text { Stunting }\end{array}$ & & \\
\hline & $\mathrm{N} \quad \%$ & $\mathrm{~N}$ & & \\
\hline Exclusive & $19 \quad 15$ & $76 \quad 60$ & & \\
\hline $\begin{array}{l}\text { Non- } \\
\text { Exclusive }\end{array}$ & 1210 & 18 & 0.027 & $\begin{array}{l}(0.155- \\
0.910)\end{array}$ \\
\hline Total & $31 \quad 25$ & $94 \quad 75$ & & \\
\hline
\end{tabular}

The study results shown in table 3 above illustrate that babies who are exclusively breastfed are not at risk of stunting, totaling 76 babies $(60 \%)$, while babies who are stunted are 19 babies (15\%). Bivariate analysis using Chi-Square obtained a p-value of 0.027 . It was indicated that there is a relationship between exclusive breastfeeding and the incidence of stunting in infants aged 6-24 months with OR (95\% CI) of 0.375 (0.155-0.910). Thereby, infants with Exclusive breastfeeding have a small risk of stunting or almost no chance of stunting.

Table 4 Relationship of mother's attitude in giving complementary foods with stunting

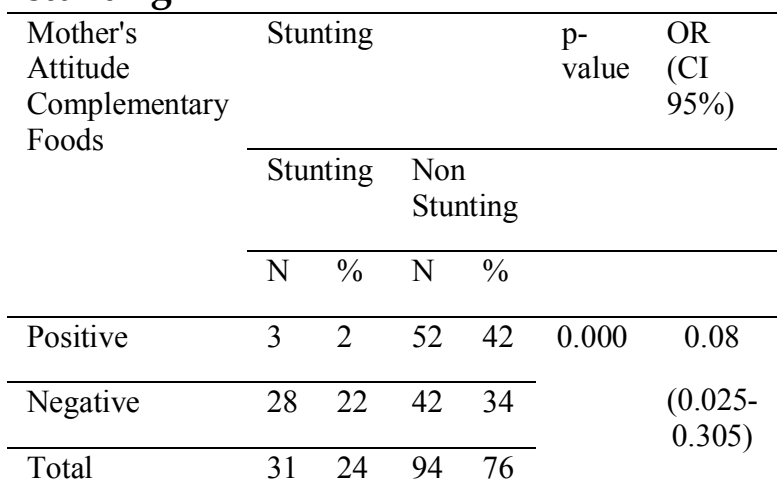

Table 4 above shows that 52 babies (42\%) cared for by mothers who had positive complementary feeding attitudes did not experience stunting, and 3 babies $(2 \%)$. The results of the analysis of the relationship between the mother's attitude in giving complementary feeding and the incidence of stunting using the chi-square obtained a p-value of 0.000 and an OR value (CI 95\%) 0.08 (0.025-0.305). The conclusion is that babies cared for by mothers who have a positive attitude in giving complementary foods have a 0.08 times risk of experiencing stunting, meaning that they are almost not at risk of stunting.

\section{DISCUSSION}

The researcher collected data on the characteristics of the respondents consisting of data on mother's education, mother's occupation, baby's gestational age, history of exclusive breastfeeding, mother's attitude in giving complementary feeding, and stunting. Fifty respondents have Senior High School Education, and 85 respondents are housewives. This study involved 100 babies born with gestational age at 37 weeks.

Most of the respondents had a history of getting exclusive breastfeeding and were cared for by mothers who had a positive attitude in giving complementary foods. At the same time, the stunting data showed that 94 babies did not experience stunting. The relationship between Infant Gestational Age and the incidence of stunting obtained $p$-value $=0.016$ and an OR value of 3.143 (95\% CI:1.03-2.35). Based on this, it can be concluded that babies born with gestational age $<37$ weeks have a three times greater risk of experiencing very short stunting compared to babies born with gestational age 37.

In addition, exclusively breastfed babies are almost at no risk of stunting. This can be seen from the score. The OR is 0.375 times, or the lowest is only 0.155 times at risk of stunting. Mothers who have a positive attitude in giving complementary foods to infants aged 6-24 months can reduce the risk of babies experiencing stunting. Based on the calculation of the Odd Ratio, the OR value of 0.08 means that infants aged 6-24 months who receive good complementary foods are only at risk of experiencing very short stunting of 0.08 times. 
This is in accordance with research conducted by Julianti (2020) (15) that there is a significant relationship between exclusive breastfeeding and stunting with a p-value of 0.001 ( $\mathrm{p}<0.005)$. In addition, the OR (Odds Ratio) value is 2.28 (95\% CI: 1.57-3.32), which indicates that children aged 12-59 months who are not given exclusive breastfeeding have a 2.28 times chance of stunting compared to those who are not given exclusive breastfeeding and Exclusive breastfeeding.

Another study conducted by Sing (2017) (24) also stated a relationship between premature birth and stunting with a p-value of 0.004 . The statistical analysis results in the study conducted by (26) showed a significant increase in body weight of children under five before and after supplementary feeding with a p-value $=$ 0.001 . The height of children under five years old also experienced a significant increase between before and supplementary feeding, both in group one $(p=0.000)$ and group two $(\mathrm{p}=0.005)$.

Health workers who include nurses and other personnel should improve the achievement of exclusive breastfeeding through efforts to provide health education and motivate mothers to give exclusive breastfeeding to their babies so that mothers understand the importance of exclusive breastfeeding compared to formula milk. This can also be done by pleasing the mother's feelings from the pre-conception period when the baby is born until at least six months and continues until the second child's birthday (12).

Socio-economic status affects health status and disease patterns. Health status, especially in children, will indirectly affect the nutritional quality of children, in this case, stunting because cases of malnutrition or stunting are often found in low-income groups. The lack of family purchasing power will impact food ingredients that can be prepared by families for their children so that it will have an impact on children's nutritional intake. Poor economic conditions do not prevent parents from preparing nutritious food for their children. Mothers are good at processing food ingredients obtained from around the house into delicious and healthy food for their children (27).

Stunting that occurs in children reflects conditions where children do not get adequate nutritional intake for a long time, resulting in non-optimal growth. Food intake is closely related to the child's eating habits at an early stage of development and depends entirely on the food provided by parents (28).

The factors that cause stunting are grouped into three: community, family, and individual factors. Community factors consist of economic, education, health, and sanitation systems. Family factors include inadequate food quality and quantity, family income, the structure of family members, parenting, and health services. In contrast, individual factors that cause stunting are poor nutritional intake, low birth weight, and a history of infectious diseases (18).

In general, babies who are declared to be born mature are babies born at 37 to 40 weeks gestation, while babies are said premature if the baby is born at less than 37 weeks gestation. Babies born at less than 37 weeks of age commonly have not wholly developed organs. This is at risk of the baby will experience respiratory failure at birth or called asphyxia. Besides, babies born prematurely are more at risk of complications during delivery. After birth, this causes the baby to take a longer treatment time compared to babies born mature with healthy conditions. In addition, several other conditions that accompany babies born prematurely are hyperbilirubinemia, ARDS babies, Hypothermia, which requires the baby to be treated in an incubator for a long time so that it will have an impact on the development of the baby at a later age. As in this study, most of the respondents were babies born at 37 to 40 weeks gestation, whereas babies born at 37 to 40 weeks gestation were assumed that the growth and development of organs had matured so that the baby was more ready to adapt extrauterine life.

Exclusive breastfeeding for babies is 
essential, considering that breast milk contains complete nutrients needed by babies to grow and develop optimally (29). The nutritional components contained in breast milk are in accordance with the baby's digestion. Besides that, breast milk also contains anti-body substances, which are very important to increase the baby's immune system to avoid getting sick quickly.

Breastfeeding only for babies for the first six months is not easy for mothers who do not understand the benefits and importance of breastfeeding, especially for working mothers. Still, in this study, most of the respondents were housewives, so most of the babies in the study. These are babies who are exclusively breastfed. The majority of mothers involved in this study have succeeded in giving only breast milk to their babies to have good growth. Most infants aged 6-24 months were exclusively breastfed in this study and did not experience stunting.

Several studies have shown that supplementary feeding intervention in the form of fish substitute snacks can improve the nutritional status of children under five. Rizki (2015) reported that supplemental feeding in biscuits and tempeh flour cakes for 30 days could increase the weight and height of children under five years old. Children under five with malnutrition and poor nutrition who consumed catfish biscuits for 88 days experienced an increase in nutrition (26). Efforts to increase the nutritional intake of children under five by providing additional food. Health workers, in this case, are nurses who have a role in providing health education to mothers who have babies aged 6-24 months. Health education that can be done is to train mothers on how to prepare menus for their children by using materials around the house. The materials used to provide other food do not have to be expensive. Still, they can be taken from the surrounding environment, arranged into an attractive menu for children. Children are more enthusiastic about eating nutritious foods so that baby's nutrition is fulfilled and babies do not experience stunting.
The existence of a relationship between the baby's gestational age and stunting shows that babies born with early gestational age have a three times greater risk of stunting than babies born at term. Therefore, health workers, especially nurses, have a role in improving health education for pregnant women to minimize the risk of premature birth, such as premature rupture of membranes, pregnant women with malnutrition status. This is in accordance with previous research that stunting control is carried out by providing interventions during pregnancy to reduce the risk of babies being born small for gestational age (30).

This study also states a relationship between exclusive breastfeeding and the incidence of stunting, where infants who are exclusively breastfed have a small risk of stunting with a chance of 0.375 or almost no risk of stunting. Nurses and midwives are expected to increase further the achievement of exclusive breastfeeding in infants aged 0 6 months by improving health services in breastfeeding motivators and breastfeeding counselors for mothers. For mothers who experience obstacles in breastfeeding, health workers also need to increase efforts to empower families to support the success of exclusive breastfeeding. This study also states that the attitude of mothers in providing supplementary food is closely related to stunting. This indicates that mothers who have babies aged 6-24 months need to be given training on how to prepare complementary foods and the importance of nutrients to optimize baby growth because babies aged 6-24 24 months require adequate energy and nutrients to grow and develop.

Nurses, in this case, are also tasked with providing health education to mothers of toddlers to avoid giving instant food and preferring to prepare their food to be given to their babies by utilizing food ingredients around the house or buying them at the market. This is also in line with previous research, which detected the risk of stunting by using the application of small area estimation techniques (31) 


\section{CONCLUSION}

There is a relationship between the baby's gestational age, exclusive breastfeeding, and the mother's attitude in giving complementary feeding with the incidence of stunting. Based on the above, it can be concluded that babies born at an early gestational age are at risk of stunting.

Exclusive breastfeeding for infants aged 0-6 months, followed by a positive attitude in preparing and providing quality complementary foods. It could reduce the risk of babies experiencing stunting, so nurses' efforts are needed to provide health education to mothers to optimize their role in infant care and nutrition. Health workers, in this case, are nurses who have a role in providing health education to mothers who have babies aged 6-24 months.

Health education that can be done is to train mothers on how to prepare menus for their children by using materials around the house. The ingredients used to prepare PMT do not have to be expensive. They can be taken from the surrounding environment, then arranged into an attractive menu for children. Children are more enthusiastic about eating nutritious foods to fulfill babies' nutrition and do not experience stunting.

\section{ACKNOWLEDGEMENT}

We thank the respondents who participated in this study. We also thank STIKES Banyuwangi for providing research opportunities. Following the publication of the International Journal of Nursing and Health Services (IJNHS) (December 2021), thanks to IJNHS for giving us the opportunity to publish this article and the reviewers for their efforts and expertise.

\section{REFERENCES}

1. Aheto JMK, Dagne GA. Geostatistical analysis, web-based mapping, and environmental determinants of under-5 stunting: evidence from the 2014 Ghana Demographic and Health Survey. Lancet Planet Heal [Internet]. 2021;5(6):e347-55. Available from: http:/ / dx.doi.org/10.1016/S2542-

5196(21)00080-2

2. Nkurunziza S, Meessen B, Van geertruyden JP, Korachais C. Determinants of stunting and severe stunting among Burundian children aged 6-23 months: Evidence from a national cross-sectional household survey, 2014. BMC Pediatr. 2017;17(1):1-14.

3. Akombi BJ, Agho KE, Hall JJ, Merom D, Astell-Burt T, Renzaho AMN. Stunting and severe stunting among children under-5 years in Nigeria: A multilevel analysis. BMC Pediatr [Internet]. 2017;17(1):1-16. Available from: http://dx.doi.org/10.1186/s12887-0160770-z

4. Iversen PO, Ngari M, Westerberg AC, Muhoozi G, Atukunda P. Child stunting concurrent with wasting or being overweight: A 6-y follow up of a randomized maternal education trial in Uganda. Nutrition [Internet]. 2021;89:111281. Available from: https:/ / doi.org/10.1016/j.nut.2021.111 281

5. Ponum M, Khan S, Hasan O, Mahmood MT, Abbas A, Iftikhar M, et al. Stunting diagnostic and awareness: Impact assessment study of sociodemographic factors of stunting among school-going children of Pakistan. BMC Pediatr. 2020;20(1):1-9.

6. Ramli, Agho KE, Inder KJ, Bowe SJ, Jacobs J, Dibley MJ. Prevalence and risk factors for stunting and severe stunting among under-fives in North Maluku province of Indonesia. BMC Pediatr. 2009;9:64.

7. Simanjuntak DR, Georgy C. Hubungan Pengetahuan, Sikap dan praktik Ibu tentang Pemberian MP-ASI dengan Kejadian Stunting di UPTD Puskesmas Beru, Kelurahan Waioti, Kabupaten Sikka Pada Tahun 2019. Repos Univ Kristen Indones. 2020;

8. Widianti D, Yusnita. Hubungan Pengetahuan Ibu Terhadap Pemberian Makanan Pendamping Asi (MP-ASI) dengan Kejadian Stunting pada Baduta di. Semin Nas Ris Inov. 2020;225:140-6. 
9. Christian AK, Agula C, JaysonQuashigah PN. Correlates and spatial distribution of the co-occurrence of childhood anemia and stunting in Ghana. SSM - Popul Heal [Internet]. 2020;12:100683. Available from: https:/ / doi.org/10.1016/j.ssmph.2020.1 00683

10. Castro-Bedriñana J, Chirinos-Peinado D, De La Cruz-Calderón G. Predictive model of stunting in the Central Andean region of Peru based on socioeconomic and agri-food determinants. Public Heal Pract. 2021;2(November 2020).

11. Yusnita, Arief A, Salsabila A, Iskandar F, Fitrihani P, Shabrina S. Hubungan Sikap dan Perilaku Ibu Terhadap Pemberian MP-ASI dengan Stunting pada Baduta di Pandeglang. Semin Nas Ris Inov. 2020;51-7.

12. Tambunan AT, Tanggulungan F, Poppy R, Sinurat F, Kartika L, Aiba S. Relationship between Mothers Knowledge and Exclusive Breastfeeding Behavior in One Private Hospital in West Indonesia. Int J Nurs Heal Serv. 2021;4(1):1-8.

13. Mutiarasari D, Miranti M, Fitriana $Y$, Pakaya D, Sari P, Bohari B, et al. A determinant analysis of stunting prevalence on under 5-year-old children to establish stunting management policy. Open Access Maced J Med Sci [Internet]. 2021;9:7984. Available from: https://doi.org/10.3889/oamjms.2021. 5622

14. Taib WRW, Ismail I. Evidence of stunting genes in Asian countries: A review. Meta Gene [Internet]. 2021;30(August):100970. Available from:

https:/ / doi.org/10.1016/j.mgene.2021. 100970

15. Julian E, Elni. Determinants of stunting in children aged 12-59 months. Nurse Media J Nurs [Internet]. 2020;10(1):36$45 . \quad$ Available from: https:/ / ejournal.undip.ac.id/index.php /medianers/issue/view/2780

16. Dinas Kesehatan Provinsi Jawa Timur.
Profil Kesehatan Provinsi Jawa Timur 2020 [Internet]. Dinas Kesehatan Provinsi Jawa Tengah. 2020. p. 1-123. Available from: www.dinkesjatengprov.go.id

17. Dinas Kesehatan Kabupaten Banyuwangi. Profil Kesehatan Kabupaten Banyuwangi Tahun 2019. Profil Kesehat Kabupaten Banyuwangi Tahun 2019. 2020;1-99.

18. Hasanah U, Maria IL, Jafar N, Hardianti A, Mallongi A, Syam A. Water, sanitation dan hygiene analysis, and individual factors for stunting among children under two years in ambon. Open Access Maced J Med Sci. 2020;8(T2):22-6.

19. Chowdhury TR, Chakrabarty S, Rakib M, Afrin S, Saltmarsh S, Winn S. Factors associated with stunting and wasting in children under 2 years in Bangladesh. Heliyon [Internet]. 2020;6(9):e04849. Available from: https://doi.org/10.1016/j.heliyon.2020. e04849

20. Ayelign A, Zerfu T. Household, dietary and healthcare factors predicting childhood stunting in Ethiopia. Heliyon [Internet]. 2021;7(4):e06733. Available from:

https://doi.org/10.1016/j.heliyon.2021. e06733

21. Vishwakarma D, Sharma SK, Puri P. Linkages between consanguineous marriages and childhood stunting: Evidence from a cross-sectional study in India. Child Youth Serv Rev [Internet]. 2021;122(December 2020):105922. Available from: https://doi.org/10.1016/j.childyouth.2 021.105922

22. Torlesse H, Cronin AA, Sebayang SK, Nandy R. Determinants of stunting in Indonesian children: Evidence from a cross-sectional survey indicates a prominent role for the water, sanitation, and hygiene sector in stunting reduction. BMC Public Health [Internet]. 2016;16(1):1-11. Available from:

http:/ / dx.doi.org/10.1186/s12889-0163339-8 
23. Tiwari R, Ausman LM, Agho KE. Determinants of stunting and severe stunting among under-fives: Evidence from the 2011 Nepal Demographic and Health Survey. BMC Pediatr. 2014;14(1):1-15.

24. Singh A, Upadhyay AK, Kumar K. Birth Size, Stunting and Recovery from Stunting in Andhra Pradesh, India: Evidence from the Young Lives Study. Matern Child Health J. 2017;21(3):492508.

25. Pender N. Health Promotion Models. Rehabilitation [Internet]. 2006;131-46. Available from: https:/ / deepblue.lib.umich.edu/bitstre am/handle/2027.42/85350/HEALTH_ PROMOTION_MANUAL_Rev_52011.pdf?sequence $=1 \&$ isAllowed $=\mathrm{y}$

26. Nadimin N, Theresia Dewi KB, Salam A, Adam A. Local snacks and virtual nutrition counseling services increasing growth of stunting children. Open Access Maced J Med Sci. 2021;9(B):3316.

27. Peni T, Ratnaningsih T, Laili SI. Factors Associated with Development among Children in Flood-Prone Areas in Indonesia. Int $\mathrm{J}$ Nurs Heal Serv. 2020;3(6):632-9.

28. Bustami B, Ampera M. The identification of modeling causes of stunting children aged 2-5 years in Aceh province, Indonesia (Data analysis of nutritional status monitoring 2015). Open Access Maced J Med Sci. 2020;8(E):657-63.

29. Wilujeng AP, Trianita D, Indriani N. Pengaruh Anticipatory Guidance Terhadap Pertumbuhan Dan Perkembangan Bayi Usia 0-6 Bulan. J Keperawatan Muhammadiyah [Internet]. 2020;5(1):11-8. Available from: http://journal.umsurabaya.ac.id/index.php/JKM/article /view/3325/2700

30. Cousens S, Perin J, Christian P, Wu LSF, Soofi S, Bhutta Z, et al. Modelling stunting in LiST: The effect of applying smoothing to linear growth data. BMC Public Health. 2017;17(Suppl 4).
31. Srivastava S, Chandra H, Singh SK, Upadhyay AK. Mapping changes in district-level prevalence of childhood stunting in India 1998-2016: An application of small area estimation techniques. SSM - Popul Heal [Internet]. 2021;14(February):100748. Available from:

https://doi.org/10.1016/j.ssmph.2021.1 00748 